\title{
What light does Matthew's use of Mark in Matthew 1-4 throw on Matthew's theological location?
}

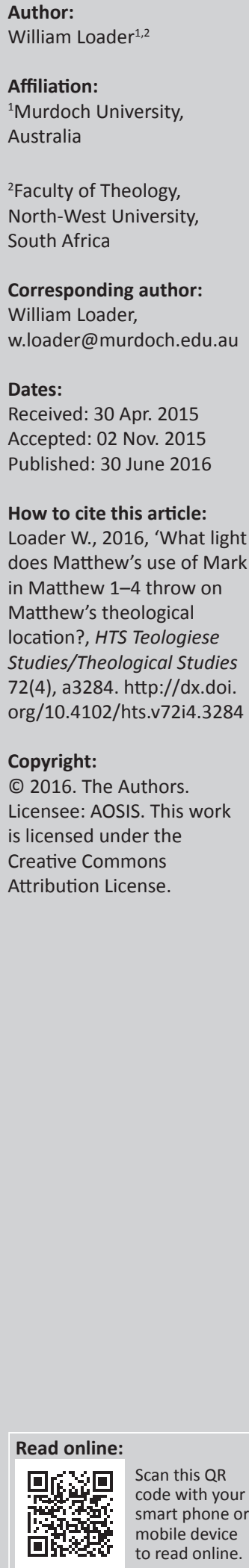

\begin{abstract}
This article approaches the issue of Matthew's theological context by examining Matthew's use of Mark, including through redaction and supplementation, in Matthew 1-4. This is undertaken in two parts: Matthew 1-2, which is largely additional material, and Matthew 3-4, followed by a concluding assessment. Issues addressed or alluded to in these chapters frequently find resonance in the remainder of Matthew's gospel and so give important clues about Matthew's concerns and their relevance for understanding its context. Such issues include the importance of messiahship; continuity with Israel, but also with John the Baptist and the Church; defence against slander; heightened christological claims; soteriology; Gentile mission; the status of Torah; and Jesus as judge to come. The article suggests a location within a Jewish religious context with a Jewish self-understanding, separate from the synagogue, but claiming to belong where its opponents would claim it did not; and a Christian tradition where the approach of ' $\mathrm{Q}$ ' to Torah is upheld in contrast to Mark's, while embracing and expanding Mark's Christology and restoring the common understanding of Gentile mission as a postEaster phenomenon.
\end{abstract}

Because this article has its origins in a presentation at the Studiorum Novi Testamenti Societas Seminar, Matthew in Context: An Exploration of Matthew in Relation to the Judaism and Christianity of its Time, it seems particularly fitting that it serve to honour the centenary of the Faculty of Theology at the University of Pretoria with this contribution in the year in which the Society will meet for a second time in this fine city.

\section{Preliminary Considerations}

Opening sections of ancient works, whether specifically designed as prologues or not, frequently identify or foreshadow major themes and emphases to follow. This underlines the usefulness of examining Matthew 1-2, but also chapters 3-4, which are preparatory in the sense of dealing with material before the ministry of Jesus began. The focus in this article is on the implications of Matthew's use of Mark in Matthew 1-4 for understanding Matthew's theological location, not primarily Matthew's use of Mark in Matthew 1-4 in itself. The article will not, therefore, redescribe the much travelled terrain of exegetical comment on these chapters, but assume it, sometimes entering into discussion of as yet unresolved or debated issues, but primarily focusing on the question: what light does this shed on Matthew's theological location? Although Matthew's use of Mark in these chapters is confined largely to Matthew 3-4, this article will take into account that to add material is also a way of responding to Mark, so will give just as much attention to Matthew 1-2. The article assumes that Matthew was written to be heard more than once, so that most hearers of the gospel would have been listening to these chapters in the light of what they have already at some stage heard, including the rest of Matthew. ${ }^{1}$ Accordingly, the discussion will take into account material throughout the gospel in interpreting these chapters.

The article will identify key themes and emphases in Matthew's use of Mark in Matthew 1-2, and then in Matthew 3-4, before turning to an assessment of their cumulative significance.

\section{Matthew 1-2}

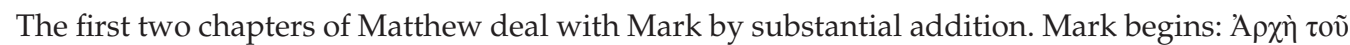

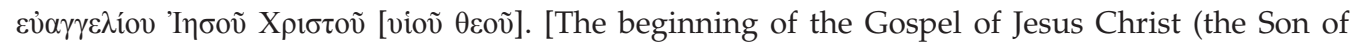
God)] (1:1), possibly as a title, possibly as the beginning of a sentence which then goes on immediately to bring a mixed citation in Isaiah's name, referring to John the Baptist (1:2-4). Whether motivated by the sense that Jesus 'the Christ' needed further explanation or exposition 
or not, Matthew replaces Mark's opening with his own formulation and proceeds to insert two whole chapters of further explanation, before coming to John. One cannot be certain that Matthew's text of Mark contained [vioṽ $\theta \varepsilon o \tilde{\text { ] }}$, and because it is a significant title for Matthew, as already 2:16 and 3:17 show, its absence here should not be read as negative or critical. The references to David and Abraham are also more suited for the introduction of the genealogy.

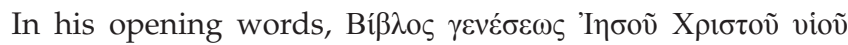
$\Delta \alpha v i \delta$ vioṽ $A \beta \rho \alpha \alpha \dot{\alpha} \mu$ ['The book of the $\gamma \varepsilon v \varepsilon \sigma^{\prime} \sigma \varepsilon \omega \varsigma$ of Jesus Christ, the son of David, the son of Abraham'], Mark's 'Jesus Christ' is supplemented with 'Son of David' and 'Son of Abraham'.

\section{The Christ, the Son of David}

In a number of ways, in these chapters Matthew presents Jesus as the royal Davidic Messiah. The genealogy highlights David as 'the king', counts the first of the three groups of 14 up to David, and overall uses the genealogy to prove that Jesus is a descendant of David through Joseph, even though he goes on implicitly to deny a biological link. The legend of Herod and the magi also has royal Messiahship as its focus. The magi see one born to be 'king of the Jews'. Herod knows this refers to 'the Messiah'. The astrology derives from Numbers 24:17, 'A star shall arise from Jacob, a sceptre from Israel', understood as referring to a single person, understood to be the Messiah (cited also in 4QTest/4Q175 9-13; 1QM 11.5-7; CD 7.18; T. Jud. 24:1; T. Levi 18:3). Bethlehem is David's city. Micah is taken as predicting that the Messiah will shepherd Israel, a motif present also in 9:36, 15:24; and Pss. Sol. 17:40 (Konradt 2007:33-41). Matthew cites Hosea 11:1 to refer to the Christ as God's son. This then gives some substance to what the heavenly voice will mean at Jesus' baptism, otherwise unmediated in Mark, 'This is my beloved Son' (3:17), though significantly more is to come.

Matthew must, therefore, have been written in a context where it made sense to elaborate on Mark's reference to Jesus as the Messiah. To do so Matthew draws on what in many instances were pre-existing traditions in order to assert and affirm Jesus' qualification to be Israel's Messiah. That it mattered enough to do so reflects at least a context where Jewish royal messianic expectations were alive and needed to be addressed. That speaks for strongly Jewish interests among Matthew's first hearers. One may wonder whether it implies that Matthew is close to the holy land which the Messiah was to liberate, but, unlike Luke for whom this aspiration, articulated in the freedom songs of his infancy narratives, remains alive (Ac. 1:6-7), this is not Matthew's focus.

By not only highlighting Jesus' qualification to be Israel's Messiah, but also depicting him as facing mortal danger as 'King of the Jews', Matthew invites his hearers to connect this story with Jesus' crucifixion, where Matthew follows Mark in depicting Jesus as crucified as 'King of the Jews' (Konradt 2007:110-13), and portrays 'all the people' (27:25) as standing in solidarity with Jesus' rejection, echoing here 'all Jerusalem' (2:3) (Konradt 2007:173). The intratextual link reinforces the sense of mortal danger associated with the messianic claim. One might speculate that it could imply that the hearers also faced danger from Herod's descendant, Agrippa 2, if they are to be found in his expansive territory. One might, with Carter, expect sensitivity to Rome's threat among all at the time and so find all claims to Jesus' messiahship, beginning

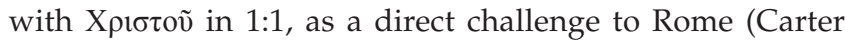
2005:42, 57). I doubt that it was top of the agenda and not appearing to be so simply because of strategic suppression. One would expect more direct or at least indirect indications if this were so. As Senior observes: 'to assert that an antiimperial stance is fundamental to Matthew's purpose seems to strain the evidence' (Senior 2011:18). Matthew's image of Pilate, in contrast to the Jewish establishment, is rather ambivalent (see Weaver 2005:126-27), though ultimately, of course, the heavens' reign would certainly be understood as ending Rome's.

\section{'Son of Abraham' - Continuity with God's People}

A strongly Jewish interest among Matthew's hearers is indicated not only by the elaboration of the royal messianic claim, but also by the initial reference to Jesus as 'son of Abraham'. It is reinforced through beginning the genealogy with Abraham. The sense of continuity with God's people and God's dealing with his people in the past is a strong feature within these opening chapters. If Joseph and his dreams, who journeyed to Egypt, evoke the memory of Joseph the dreamer who came to Egypt, though under different circumstances, the time in Egypt and then the return from Egypt evoke memories of Israel's exodus. Typological matching connects Herod's slaughter of the children with the killing of the Hebrew babies in Egypt, and through the allusion to Balaam's prophecy of the star with Balak's designs against Israel. The typological identification of Jesus with Israel continues in the account of the testing in the wilderness in 4:1-11. Similarly the rescue of the infant Jesus, the advice and wording of the angelic warnings and the advice about danger and safety connect Jesus with Moses, as does later the placing of Jesus' teaching about the Law on the mountain in 5:1, a creative reworking of Mark's narrative of the appointment of the disciples (3:13-19).

The effect of the typology is to reinforce identity. Jesus is a son of Abraham, belongs to Israel, follows the pattern of Israel, faces its dangers, and is finally a kind of new Moses. This all makes sense in a context where such continuity and identity mattered, thus, again, as with the royal messianic hope, indicating a strongly Jewish environment. The formula quotations reinforce the connection, showing that Jesus not only matches the patterns of God's action in the past, but fulfils what was seen as divinely inspired prophecy, something which would be valued by those holding Jewish scripture in high regard. 


\section{The Genealogy: Divine Planning}

The structure of the genealogy, where Jesus comes at the climax of what is depicted somewhat loosely as three sets of fourteen generations, or, as many would have seen, therefore, six lots of seven, making Jesus the seventh of seven, would have made sense to people sharing such numerological presuppositions and interpreting them theologically as reflecting divine intent (Hagner 1993:6-7; cf. France 2007:31). The somewhat artificially contrived pattern of $3 \times 14$, rather than $6 \times 7$, was probably dictated by the need to highlight David, and is typical of such patterns being imposed on history in apocalyptic literature to indicate divine control. It may originally have had even stronger Davidic links, because the three letters of David's name have the numerical value of 14, something bilingual people among Matthew's readership may have recognised (Davies \& Allison 1988:163-165; Luz 2002:136, though questioning whether Greek speakers would catch the allusion). Such numerology, like the interventions through heavenly dreams and angelic instructions, a special feature of both Matthew's infancy and his passion narratives, might occur across a range of cultures of the time, but was certainly consistent with a Jewish religious environment. It may reflect a stream of Judaism where heavenly visions featured, such as in apocalyptic literature, which would cohere with the additional apocalyptic colouring which Matthew brings, both in sayings about the Son of Man and judgement $(13: 41-43 ; 25: 31)$ with parallels in the Parables of Enoch ('throne of his glory') (1 En. 61:8; 62:2-5; 69:27) and in narratives such as the earthquakes and resurrections (27:5153; 28:2). Notably among Matthew's additions to the passion narrative is the dreaming wife of Pilate.

\section{The Virginal Conception, Emmanuel and Big Christological Claims}

Standing somewhat in tension with Matthew's use of the genealogy to show that Jesus is a descendant of David, an emphasis reinforced when he has Joseph addressed by the angel as 'Son of David' (1:20), is the account of the virginal conception. If the elaboration of Jesus' royal messianic identity serves, at least in part, to background or elaborate Mark's 'Jesus the Christ', the miraculous conception serves to background further the unmediated heavenly acclamation, 'You are my beloved Son' in Mark's baptismal story, which Matthew turns into a public statement, 'This is my beloved Son' (3:17). 'My Son' occurs also in the citation from Hosea $11: 1$ in 2:15. Its basis there and at the baptism is the miraculous conception.

Matthew highlights from his tradition the allusion to Isaiah $7: 14$, which may have generated the miracle story in the first place, by citing it directly. Matthew uses the name 'Emmanuel' to imply that through Jesus God is with us, but, seemingly, at least initially, not by direct identification as God, but through what he does. The focus falls on Jesus as the one who 'shall save his people from their sins' (1:21). Those familiar with Matthew's account may well have recognised an inclusio with Jesus' final words with which the gospel ends: 'Behold,
I am with you always to the end of the age' (28:20). It is not an exact match and not claiming Jesus as God. The context of these words is not a claim to be God, but a claim to be authorised by God (28:18).

On the other hand, what is promised here echoes what was said of God's Shekinah in early rabbinic tradition and finds expression in the promise of Jesus' presence when the church is adjudicating on cases of discipline. As Shekinah is promised where a handful gather to interpret Torah ( $m$. 'Abot 3.2, 3), so Jesus claims he will be present when his followers do the same (18:20). This is an extraordinary claim exhibiting a Christology which would have gone far too far for most Jews who might otherwise have tolerated the authorisation model. It is matched by what we can recognise - and some of them might have recognised - as the appropriation of Wisdom's persona by Jesus in Matthew (11:28-30; cf. Sir 51:23-26; 23:34-35; cf. Lk. 11:49-51). Emmanuel signals therefore, especially for hearers familiar with what is to come, not just God's presence through Jesus' coming activities, as to be expected in anyone acting as God's agent, such as a Messiah, but an implicit claim, which, although falling short of a claim to be God with us, comes from a Jewish perspective perilously close to being blasphemous, a claim of identity with divine emanation, and would give credibility to the high priest's charge at the Jewish trial (26:63-65). Mark's version of the Jewish trial (14:61-63), the source of Matthew's, is probably already a reflection of charges made against Christian claims for Jesus in his day, rather than belonging to the last days of the historical Jesus. This is almost certainly the case also with Matthew's account. We might reasonably expect that many of Matthew's contemporary Jews would have looked askance at such claims and deemed them beyond the pale and so agreed with Matthew's Sanhedrin.

\section{'He shall save his people from their sins'}

'He shall save his people from their sins' (1:21) is the only reference in Matthew 1-2 to what Jesus, the Messiah, Son of David, son of Abraham, would do. Claiming to be or claiming anyone to be the Messiah was fraught with difficulty and needed careful attention to ward off misunderstandings. To 'save his people from their sins' may be little more than a relic of popular etymology, or it could indicate, as is more likely, that Matthew sees this as Jesus' primary role. 'His people' may now focus on more than just Israel (Davies \& Allison 1988:210; France 2007:53; Hagner 1993:20). One might make a connection with his addition to Mark's account of the last meal where to 'This is my blood of the covenant poured out for many' (14:24) Matthew adds 'for the forgiveness of sins' (26:28). One might even argue that this indicates that Matthew shares with Paul and others the understanding of the gospel according to which 'Christ died for our sins' (1 Cor. 15:3) and that this was the all important transaction which effected atonement, including forgiveness of sins, in this sense bringing Matthew closer to Paul than Mark with whom he shares the ransom saying (20:28; cf. Mk 10:45), but whose saying over the cup he supplements (26:28; cf. Mk 
14:24). This would then indicate that Matthew has moved so far into certain streams of early Christian thought that atonement now rests solely on Christ's redemptive act. One could find further evidence for this in Matthew's editing of Mark's account of John the Baptist's message, where Matthew omits Mark's description of John's baptism, as 'for the forgiveness of sins' (Mk. 1:4) (Davies \& Allison 1988:292). It would be very hard to conceive of Matthew still seeing himself as belonging within Judaism when holding such a stance, let alone for his Jewish contemporaries for whom such a claim would be seen as effectively debunking what God had given in Torah.

Matthew does not, however, give the impression that he now limits such forgiveness to something achieved by Jesus' death. Although he omits 'for the forgiveness of sins' (Mk. 1:4), he still implies that this was the purpose of John's baptism when he reports that people were baptised confessing their sins (3:6). This surely implies that he still understands John's baptism as bringing forgiveness (Hagner 1993:47; Varkey 2014:99-102; cf. Davies \& Allison 1988:300-301; Repschinski 2009:74). Elsewhere he shows no compunction in repeating Mark's story according to which Jesus declared God's forgiveness to the paralytic (9:2, 5-6; cf. Mk 2:5-10) and the saying according to which one's forgiveness depended on one's forgiveness of others (6:14-15; cf. Mk 11:25); and from $Q$ the Lord's Prayer with its bidding for forgiveness (6:12).

'For the forgiveness of sins' (26:28) as an addition to the word about the blood must be given its weight, but, much as in Mark, should not be turned into the major role definition of Jesus as might fit Paul. So its addition might well not have been so potentially offensive to his contemporaries, who could also contemplate vicarious suffering by others. It is also not clear that to 'save his people from their sins' does necessarily refer to atonement. Does it mean saving them from the consequences of their sins, a traditional role of the Messiah who would lift Israel from defeat to victory over its enemies? Hagner notes that 'the natural expectation regarding the significance of $\sigma \dot{\sigma} \sigma \varepsilon l$, "will save", would be that it refers to a national-political salvation', but suggests that the focus is sins and that Matthew 'may be giving a targumic rendering' of Psalm 130:8 ('It is he who will redeem Israel from all its iniquities') (Hagner 1993:19). France argues that this role description sets Jesus' messiahship apart from those with political associations (France 2007:54). Carter suggests that Matthew has in mind the sin of rejecting Jesus on the part of both the Jewish establishment and Rome (Carter 2000:69-70). Does it mean saving them from being engaged in sin? Does it mean some combination of these, including forgiveness? Konradt, sees 1:21 as umfassend als Vorzeichen vor dem Wirken Jesu in Israel fungiert, das im Tod 'für die Vielen (26:28) seinen soteriologischen Zielpunkt findet' (Konradt 2007:50). Davies and Allison suggest that 'perhaps, then Matthew thought that Jesus saved his people from their sins in a variety of ways', identifying Jesus' healings and his abiding presence beside 26:28 (Davies \& Allison 1988:210). Similarly Carter proposes that 'it embraces Jesus's words, actions like healings and exorcisms, feedings and meals, his death, resurrection, and return when he overcomes Roman rule and all that resist God's purposes (24.27-31)' (Carter 2005:156). The consideration of the role definition given in Matthew 3-4 suggests such a broader meaning. To this we return below. It also has implications for how we might understand Matthew's context, both in relation to Judaism's and in relation to the Christian movements.

\section{Slander and Respect}

The claim of a miraculous conception without male sperm, not unparalleled in Jewish literature of the time, as 2 Enoch demonstrates in relation to the birth of Melchisedek (2 En. 71-72), appears likely to have spawned ridicule, such as we find explicitly later in the gospel in the allegations that the tomb was empty because the disciples stole the body (27:62-66; 28:11-15). Although Matthew does not report allegations about Mary, it seems likely that the addition of the women to his genealogy is designed to counter just such allegations. For here, too, are women about whom rumours or reports suggested illicit sexual behaviour, whether complicit or not. The issue is not primarily to assert that women, too, belong as significant within God's action with his people, for then we should have expected some of the other less controversial figures like Sarah, Rebecca, and Hannah.

Davies and Allison point to the occurrence of such slander in later literature: Acts Pil 2:3; Orig Cel 1.28. 32 Tert Spec 30 (Davies \& Allison 1988:220). The counter-argument by France that such embarrassing women were not likely to have been so for them (France 2007:37) is not cogent, and Luz's observation that their irregularity is diverse and Mary's depiction differently formulated (Luz 2002:134-135) does not alter the likely offence. Kennedy notes that Chronicles also includes Tamar and Bathsheba (1 Chr. 2:4; 3:5) and argues that their inclusion has nothing to do with wrongdoing or being foreign, but they serve as reminders of Israel's story (Kennedy 2008:71, 86), though he acknowledges that 'the 'irregularity of the stories, which is mirrored by the "irregularity" of Mary and Joseph's situation (Mt 1:16, 18-25), could possibly be a subsidiary component' (87).

This suggests that Matthew is written in a context where such allegations were being made about Mary, probably only after Christians claimed the miraculous conception. This at least suggests a context where countering such allegations mattered, in other words, where those making them were close enough for them to hurt and so needed to be answered. Indeed, France goes even further when he writes of 1:18-2:23: 'These thirty-one verses are therefore essentially an exercise in apologetics' (France 2007:41-42). This will certainly lie behind the efforts made in these two chapters to show Jesus as Davidide and as born in Bethlehem.

The special depiction of Mary inevitably required that Matthew remove the negative implications about Jesus' family found in Mark. Thus, Matthew removes the suggestion that Jesus' family thought he was mad (Mk 3:21), part of the sandwich structure which envelopes the scribes' charge that 
he was even in league with Beelzebul (3:20-35), though he retains Jesus' comment about prophets not being accepted in

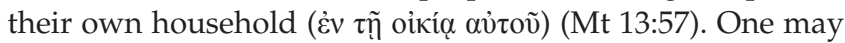
ask whether the more sympathetic treatment, at least in part, implies something more; namely that Matthew has some relation to those branches of Christianity connected with the Jerusalem church where Jesus' family was held in high esteem. One might then contrast this with a construction of Mark's setting which sees him in tension with such churches. But neither in Mark nor in Matthew need this be so (see Loader 2014; cf. Sim 2011:180, 186).

\section{Gentiles}

Each of the women in the genealogy, with the exception of Mary, was also a Gentile. Might Matthew have intended their presence also to function as legitimation of Gentiles now being included among God's people? (Konradt 2016:33; Kraus 2011:206; Luz 2002:135; cf. Nolland 2005:77; Sim 1995:22). Those familiar with Matthew's version of events would know that Jesus forbid Gentile mission during his ministry (10:5-6), sanctioning it only after his exaltation. They could have seen the legitimation foreshadowed in the genealogy. More secure is the allusion to future Gentile response in the coming of the magi to hail the Jewish Messiah (Davies \& Allison 1988:253; France 2007:67; Hagner 1993:31; Konradt 2016:35; Kraus 2011:206; Nolland 2005:118). The motifs derive from prophetic expectation that Gentiles would come to Zion to acknowledge Israel's God (Ps. 72:10-11, 15; Is. 60: 6). Such traditions, sometimes referring to Gentile kings and to gifts of gold and frankincense, inspired Matthew's account (as well as its later elaborations). One might also argue that the astrological imagery of the star implies a universal perspective.

Some have seen already in 1:1 an allusion to gentile mission, namely in the reference to Jesus as 'son of Abraham', which Luz deems auffällig (Luz 2002:119). According to Genesis 12:3 (cf. also 18, 18; 22, 18; 26, 4) Abraham was to be father of many nations and all would be blessed in him. Paul certainly exploits this tradition in arguing for the inclusion of Gentiles on the same basis of faith as Jews. Wolfgang Kraus (2011) writes:

'Es ist allgemein anerkannt, dass Mt 28,20 mit Mt 1,23 eine große Inklusion bildet. Was weniger betont wird, ist die Inklusion, die von Mt 28,19 mit Mt 1,1 gebildet wird. (p. 204; similarly Charette 1992:66-72; Davies \& Allison 1988:138-140; France 2007:35; Konradt 2016:35)

Though the following context applies the reference to Abraham nationally (cf. Nolland 2005:72). One might cite the allusion to non-physical sonship of Abraham in 3:9, which Matthew's hearers would surely have connected to the Gentile issue (Davies \& Allison 1988:309; France 2007:111; Hagner 1993:50; and more tentatively: Kraus 2011:206, 208), though probably not John the Baptist's original intent.

\section{Law}

There is specific reference to the Law when Matthew writes of Joseph's being confronted with Mary's pregnancy, which he took as proof of $\pi$ opveía during their betrothal, the equivalent of adultery: Joseph 'being a righteous man and not wanting to expose her to public shame, chose to divorce her privately' (1:19). The Law provided two options. He chose the more compassionate one, in line with what Matthew's Jesus teaches about exposition of the Law and the righteousness it demands (5:21-48). It cannot mean in Matthew, being a righteous man, 'but' (cf. Brown 1993:84-85; France 2007:51). It must mean being a righteous man, 'and', to which we might add 'therefore'. The alternatives are not: keeping the Law or being compassionate, because righteousness in Matthew means fulfilling the Law as Jesus expounded it, thus giving weight to its greater priorities like compassion (cf. 5:19; 23:23) (similarly Hagner 1993:18; Luz 2002:148; Nolland 2005:9495). The requirement of divorce is not a retreat from a strictness which forbid divorce altogether, as most still read Jesus (Mk 10:10-12; Lk 16:18; 1 Cor 7:10-11), which would amount to a most uncharacteristic retreat for Matthew, but simply enacting what we do not, but they all did presuppose, namely that adultery mandates divorce (see Loader 2012:286287; Loader 2015a). For the application of Gen 2:24 is twosided: becoming one flesh means a permanent join (Mk. 10:6-9; Mt. 19:4-6) and becoming one flesh with another means severing the original, as Paul's use of the text confirms (1 Cor. 6:15-20). In any case what we read here coheres with Matthew's expositions later about the Law and greater righteousness, and, as hardly needs stating, confirms that he is in a context where Torah observance matters. Sometimes the focus is simply on doing the will of God, as in doing all righteousness in 3:15 (Repschinski 2009:75-76), but that is not in tension with doing Torah or acting with compassion, because all are rooted in Matthew's understanding of God as compassionate.

\section{Matthew 3-4}

When we reach Matthew 3-4, we have already heard or heard again who Jesus is: Israel's Messiah, whose birth and infancy fulfils scripture and matches God's actions in the past; and God's Son, miraculously created through Mary's conception by divine aid. We have also been alerted to the Gentile issue. There has already been a description of Jesus' role: 'to save his people from their sins', which is capable of a range of meanings. Differently from the first two chapters in which Matthew reworks traditions associated with Jesus' birth and infancy, Matthew 3-4 shows Matthew reworking Mark and supplementing Mark with $Q$ material and additional comment. Our focus is not reconstruction of the source material, nor just Matthew's use of Mark, but what light it may shed on Matthew's theological location. There are many minor changes evident in Matthew's redaction. Our concern is above all with distinctive themes and emphases.

\section{John - Jesus - the Church in Continuity}

The first most striking change is that Matthew summarises John the Baptist's preaching with the same words with which he summarises Jesus' preaching. It is a reworking of Mark

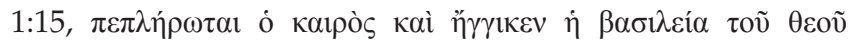




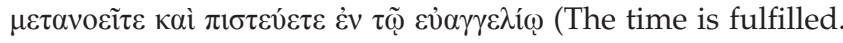
The kingdom of God is at hand. Repent and believe the gospel), which forms an inclusio with Mk 1:1's reference to the Gospel of Jesus Christ. Matthew simplifies the summary

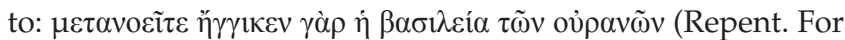
the kingdom of heaven is at hand), and repeats it in identical form in 3:2 of John, 4:17 of Jesus, and also 10:7 of the preaching of the disciples. The continuity among all three is later evident in Matthew's supplementing Mark's single parable of the wicked vineyard tenants (Mt. 21:33-46; cf. Mk. 12:1-12), which follows the exchange about Jesus' authority after his action in the temple (Mt. 21:23-27; Mk. 11:27-33), with two further parables $(21: 28-32 ; 22: 1-14)$, creating three to reflect on responses to the three: John, Jesus, and the disciples. Thus Matthew sets in parallel and continuity: rejection of John (described as coming in the way of righteousness), rejection of Jesus (in Mark's original parable of the vineyard), and rejection of the disciples (the parable of the wedding feast).

Matthew connects the authority of all three, but clearly not in a way that equates their status, as the exchange before Jesus' baptism illustrates (3:14-15). He does, however, do so in a way that equates their message. Compared with Mark, Matthew thus makes John more like Jesus, and conversely, Jesus more like John. The call of both to repentance assumes forgiveness of sins, also an element in what is seen as Jesus' role to save people from their sins. More significantly, John announces that Jesus is to be the judge to come and declares the basis of judgement (3:7-12). This significantly supplements the sparse reference to Jesus' role in Matthew $1-2$. Now we see that Jesus is the judge to come, a superior status, but the basis of judgement is, as one would expect, the same as in John's preaching.

\section{Jesus, the Judge to come}

In Mark's account John predicts Jesus' coming as the greater one who will baptise with the Spirit, which he proceeds to do in his Spirit-empowered ministry, overcoming the demonic. Matthew has supplemented Mark's account with material drawn from $Q$, showing John as predicting a coming judge who will baptise with fire and declare the basis of that judgement (3:10-12). The effect in Matthew of the baptism of Jesus and the divine declaration of Jesus as God's beloved Son is to identify Jesus as the one of whom John spoke and, more specifically in Matthew, therefore as the judge to come. Saving from sin thereby takes on a broader meaning which includes forgiveness, but also declaring the basis for living a life without sin. The juxtaposition of John's prediction and the heavenly voice declaring Jesus Son of God, has the effect of giving the title Son of God a particular content informed by that role description. This has major implications not only for Matthew's Christology, but also his soteriology and the way Matthew and his community understand themselves in their theological context.

It coheres with this emphasis that the words of John about judgement, 'Every tree which does not bear fruit shall be cut down and cast into the fire' (3:10), appear again as Jesus' words in 7:19 as the so-called Sermon on the Mount reaches its climax. This is more than the duplication of a saying. It represents an identity of message, as 3:2 already implies. As well as identifying this common saying, France also lists other features in common between John and Jesus: 'brood of vipers' (23:33; 12:34); call to repentance (11:20-21); challenge to bear fruit $(7: 16-20 ; 12: 33 ; 21: 41,43)$; allusion to Abraham's children (8:11-12); judgement by fire $(5: 22 ; 13: 40-42$, 50; $18: 8-9 ; 25: 41)$; and gathering grain (13:30) (France 2007:98).

The construal of Jesus as judge to come must deal with the discrepancy that Jesus does not perfectly match John's prediction. He does not appear brandishing fire. Matthew can use the Q material reflecting that dilemma, when John's disciples question if Jesus then truly can be the one whom John predicted, explicitly identified as the Messiah in Matthew's version, only to be told that indeed John should not be offended, but take note of what he has been doing (11:2-6). The resolution in $Q$, taken over and further developed by Matthew, is that Jesus brings the predictions of John to fulfilment in two stages. During his ministry he fulfils the mission of Israel's Messiah manifesting the miracles of healing predicted for the messianic age and in the future he will come as judge. Hence Matthew adds the messiahship motif to the introduction to John's question in 11:2 ('John, hearing in prison about the deeds of the Christ ...'; cf. 'And his disciples reported about these things to John ...' Lk. 7:18).

Without question the motif of Jesus as judge is prominent in Matthew's depiction of his roles, including the brandishing of fire in judgement. We see this as a regular feature, especially as Matthew brings Jesus' speeches to their climax. But it also has a direct impact on how Matthew portrays Jesus' ministry on earth in which a central aspect is proclaiming and expanding divine law. For the judge to come announces in advance the basis of judgement. That basis matches both what John declared and what the disciples would declare as they would go out to teach what Jesus had commanded them (28:19).

This represents a major reworking of the understanding of Jesus' role. He is not just the one who brings liberation and its promise, as in Mark. He is the judge, who in an act of God's grace declares the basis of judgement in the present and calls to repentance so that people will be saved from their sins. Jesus, like John, is a preacher of judgement. This also makes sense of Matthew's expanded citation of Isaiah 42:1, first alluded to in the heavenly voice at Jesus' baptism (3:17), to include all of Isaiah $42: 1-4$ in $12: 18-21$. It is the role description already implied in that first allusion to Isaiah 42:1 at Jesus' baptism in the reworked Matthean context, namely, that Jesus is the judge. It hails him again as God's Child or Son (o $\pi \alpha i \tau \varsigma \mu o v)$ and makes his role explicit:

I shall put my Spirit upon him and he shall proclaim judgement

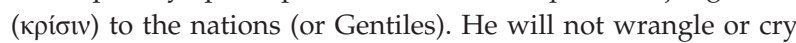
aloud, nor will anyone hear his voice in the streets. He will not break a bruised reed or quench a smouldering wick until he brings judgement ( $\kappa$ íøıv) to victory. And in his name the nations (or Gentiles) will hope. (12:18b-21) 
This addition by Matthew comes immediately after two controversies about interpreting Torah, eating in the grain fields and healing a withered hand on the Sabbath (12:1-14), which are directly juxtaposed to Jesus' cry as the embodiment of Wisdom and/or Torah:

Come to me, all you that are weary and are carrying heavy burdens, and I will give you rest. Take my yoke upon you, and learn from me; for I am gentle and humble in heart, and you will find rest for your souls. For my yoke is easy, and my burden is light. (11:28-30)

Its gentleness forms an inclusio with the citation from Isaiah 42:1-4 ('He will not break a bruised reed or quench a smouldering wick'). Here Matthew presents Jesus as expounding God's law, the basis of judgement to come.

Proclaiming judgement 'to the nations (or Gentiles)' (Is. 42:1) happens only after Easter according to Matthew when the disciples are commissioned to teach all nations what Jesus has taught them, but we see its implications clearly in the parable of judgement which Matthew makes the climax of Jesus' ministry, where all nations are summoned before the Son of Man (25:31-46).

A further element which supports this transformation is Matthew's development of Moses typology, identified in discussing the first two chapters and which comes to expression in having Jesus ascend a mountain, like Moses, in the context of teaching about the Law (5:1). It fits Matthew's redefinition of Jesus' role that the first event of his public ministry is not an exorcism as in Mark 1:21-28, but the teaching given in Matthew 5-7. Matthew notably deletes the exorcism in the synagogue, but uses its contrast between Jesus' authority and that of the scribes as the climactic comment on his teaching: 'he taught them as one having authority and not as their scribes' (7:28-29; cf. Mk. 1:22), which may well be acknowledging Jesus as also performing a scribal role, as would the disciples according to Matthew (13:52), but in both cases with greater authority. This is another instance also of Matthew supplying what is deemed to be missing in Mark: reference to his teaching in Mark 1:21-22 before any actual teaching has been recorded.

\section{Gentiles}

We have already noted the potential allusion to inclusion of Gentiles in the way John the Baptist's warning about being children of Abraham might have been heard by listeners to Matthew: 'And do not suppose to tell yourselves, we have Abraham as our father. For I tell you, God can raise up children to Abraham from these stones' (3:9). They would have had to have been dense not to have made a connection with the Gentiles mission. In Matthew the temptations end with the climax of the devil offering Jesus 'all the kingdoms of the world and their glory' (4:8-9). Although the language is not the same (Nolland 2005:167), the irony of Satan offering what God alone finally gives as the foundation for the gospel going to all nations (28:18-19) (Davies \& Allison 1988:404) is scarcely to be missed and fits Matthew's order of the temptations, where this one forms the climax. The previous two temptations may well be rejecting models of messiahship focused on signs and wonders. All three play typologically with the story of Israel's failure in the wilderness. The broader focus finds confirmation also in the report which immediately follows of Jesus' departure for Galilee, portrayed in Matthew's citation of Isaiah 8:23-9:1, which speaks of 'Galilee of the Gentiles', and continues: 'the people who sit in darkness have seen a great light and on those sitting in the region and shadow of death a light has dawned' (4:15-16). Its focus is Jesus' ministry which is about to commence with his proclamation in 4:17, his recruitment of disciples in 4:18-22, and his work around Galilee, but the allusion to Galilee of the Gentiles and to the darkness foreshadows the expansion of the mission later to the Gentiles (28:16-20) (Davies \& Allison 1988:382, 385; France 2007:143; Hagner 1993:73-74; Konradt 2016:35; Kraus 2011:206; Luz 2002:235; Cf. Nolland 2005: 15-16). Thus, Luz points to the way that the ending of the prologue matches that of the gospel (Luz 2002:123).

\section{Synagogue}

Matthew appears to be responsible for turning John the Baptist's address to the crowds about not being presumptuous about being children of Abraham into an attack on the

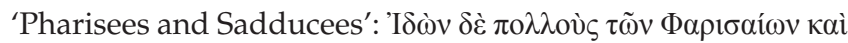

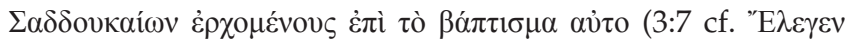

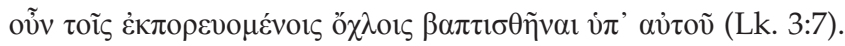
The presence here of Sadducees is probably deliberate on Matthew's part (Luz 2002:207) and belongs to his attribution of guilt to them as well as to the Pharisees for the death of Jesus, even though they are no longer part of the opposition in his own day, having not survived the events of 66-70 CE. Thus, although the reference to Sadducees tells us little of Matthew's situation (cf. also 16:1, 11-12; 21:45-46), the reference to Pharisees, by contrast, as in the rest of the gospel, reflects conflicts of Matthew's community. It is significant that in contrast to Luke (and probably Q), Matthew does not depict them as coming to be baptised.

In 4:23 we also find the first of many references to 'their' synagogues (9:35; 10:17; 12:9; 13:54; 23:34). As Konradt observes: 'In den Summarien des Erzählers in Mt 4,23 (par Mk. 1,39) und 9:35 kann man 'ihre Synagogen' auf die Synagogen in Galiläa beziehen, ohne dass eine Distanzierung sichtbar wird' (Konradt 2016:6).

\section{Evaluation}

Much more difficult than delineating Matthew's transformations in his use of Mark is the question what light they may shed on his theological location. Let me venture the following.

Matthew appears to assume that his hearers, who will be believers, would find the legitimation of Jesus' messiahship and the connections with God's engagement with Israel, expressed in genealogy, typology, and fulfilment of scripture, important. Messiahship remains a theme, in particular in 
relation to Jesus' ministry, as he exercised roles associated with the Son of David as healer. The affirmation that Jesus was God's Son, created by miraculous conception, would have been significant over against allegations that dismissed the claim and the miracle as masking something shameful and ill-fitting divine involvement.

These observations take us little further than the observation that Matthew's believers are well acquainted with and share Jewish hope which they see realised in Jesus and are close enough to other Jews who dispute them and their basis, to say that Matthew must be operating in what was primarily a Jewish religious environment, something reinforced by such allusions to Jewish administration as we find in 23:1-3, where they are encouraged to obey local Jewish authorities.

Such a setting also makes sense of Matthew's placing God's Law at the centre of Jesus' message. The structural pattern of Matthew's theology matches that of most Judaism's we know of at the time: the response of believing and accepting what God promises and the commitment to change and lead a life of observance of God's Law. The two new elements are: that God has promised something through Jesus (but it is something thoroughly Jewish) and that responding to it entails keeping God's Law specifically as expounded by Jesus. We might call it Jesuanic Judaism. It is Judaism with addition, not in any sense a break - at least as viewed from Matthew's side. Its soteriology is framed by expectation of divine judgement, associated with the coming of Jesus, as was the soteriology of Paul and Mark, and leaving aside the christological component, by most Judaisms of the day. It differed from Paul in retaining a fundamentally Jewish soteriology: one finds life by keeping the commandments. In contrast to Paul, it shares this with Mark, whose answer to the question of how to inherit eternal life it willingly adapts (19:16-22; cf. Mk 10:17-22), but differs from Mark in demanding obedience to all of Torah, retaining both the greater ethical demands, which Mark espouses, and the lesser ones, such as tithing $(5: 17 ; 23: 23)$ and food laws, which Mark drops (Mk. 7:15-19).

Its Christology matches this soteriology in depicting Jesus as judge to come who has by grace come to expound what kind of adherence to Torah he as judge will demand of all in the end. More significantly, Matthew's reconfigured portrait of Jesus' role takes his significance beyond Jewish concerns with a Messiah, which Jesus fulfils, to the role of universal judge. The judge's exposition of the Law focuses typically on those aspects of Torah which are applicable to both Jews and Gentiles, namely with a strong focus on the ethical, rather than the cultic and ritual, despite the rhetoric of not dispensing with a stroke of a letter which Matthew still presupposes.

A further important element in these chapters is involvement of Gentiles. In Matthew 1-2 the legend of the magi, reworking the generous strands of Jewish tradition promising a place for Gentiles, possibly the Gentile women of the genealogy, and allusions to 'son of Abraham', signal its importance. In
Matthew 3-4 stones becoming children of Abraham, the irony of the last temptation foreshadowing 28:18-20, and the mention of Galilee of the Gentiles keep the focus alive. The radical role definition of Jesus identified as the universal judge to come announced by John through the voice at his baptism, now articulated in 12:18-21 through the expanded citation to which that voice alludes, namely Isaiah 42:1-4, indicate that the role John predicted of Jesus is one he is to fulfil by announcing judgement to the nations, including, therefore, the Gentiles (Kraus 2011:206-207). It coheres with this emphasis that Matthew has Jesus' public ministry end with a parabolic account of the last judgement where all the nations are arraigned before the Son of Man to answer for how they treated his missionaries, obviously including missionaries to Gentiles as well as Jews, otherwise the judgement would not make sense. This only makes sense if the Gentile mission has been underway for some time.

The development of a universal focus behind Matthew's portrait of Jesus will not have happened overnight, but appears to reflect considerable thought about Gentiles' belonging in the people of God. Matthew is clear that Jesus' own ministry did not have this focus, but shares this view also with Luke, who depicts the inauguration of Gentile mission in Acts, partly by accident at first, and with John, for whom Gentiles come to approach Jesus only at the very last $(12: 20-22 ; 12: 19)$ and their being drawn is designated a postexaltation event (12:24, 32). Mark's insertion of a Gentile mission into Jesus' earthly ministry was an artificial construction in which Mark used symbols and numerology to have miracles affirm Gentile inclusion, especially through the feedings of 5000 Jews with twelve baskets left over and 4000 Gentiles with seven (6:32-8:10; similarly the matching Jewish and Gentile panels in 5:1-43). Matthew notably undoes the construction and Luke omits it. We should not see Matthew's limitation of the mission to Israel as innovative, let alone as suggesting replacing mission to Jews with mission to Gentiles because of failure of the former (so rightly Konradt 2016:12; similarly Kraus 2011:205), but rather as historicising Mark's symbolic narrative, to bring it into line with the way everyone else, it seems, believed things happened. It was Mark who was being innovative. As in John, Matthew sees the exaltation as marking the turning point, as a result of which mission to the world is to begin, closely associated with the notion that that exaltation entails enthronement or authorisation, as the sequence in 28:18-19 suggests. Nothing suggests that this is connected to Christ's death as an act of atonement, as Konradt speculates (Konradt 2016:36), any more than it is in John.

As Luke reduces the centurion's confession to a declaration of Jesus' innocence, because Gentile mission starts later (Lk 23:47), so Matthew makes it clear that the other centurion's faith was a foretaste of what was to come (8:5-13), as later was that of the Canaanite woman (15:21-28), both shaming Israel's failure in faith. Matthew is very clear about the future from the perspective of Jesus' ministry: 'Many will come from east and west and sit at table with Abraham, Isaac, and Jacob in the kingdom of heaven' (8:11-12), for this gospel is to be preached to all peoples $(24: 9,14)$, even though, like Paul, 
Matthew knows that the appropriate sequence in the divine plan is: Jew, first, and then Greek (cf. Rom 1:16-17; 2:9; Mk

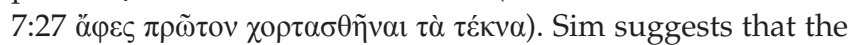
soldiers' acclamation in 27:24 is a confession of guilt rather than of faith (Sim 1993:418-422, 2005:104-105), but in any case Matthew reflects an historical pattern. The commissioning of the disciples during Jesus' ministry (10:5-6) makes it clear that their mission is first to Israel and they are not to enter Gentile territory and that mission will continue to the end despite rejection (10:23), just as Jesus, himself was sent only to the lost sheep of the house of Israel (15:24).

This does raise the question: if these restrictions in 10:5-6 are superseded, why mention them at all and how credible is it that Jesus inaugurated such a mission during his ministry? If we do not dismiss their presence as incidental baggage from the past which a sharp editor might have cut (on this see Hagner 1993:1xx), they must have been significant enough for this community to be retained, leading to the probability that they reflect a stage behind Matthew where mission to Gentiles was not accepted (not even in the form of proselytism). That is scarcely the case now in Matthew's community, which allows one to speculate whether Matthew is including these statements out of pastoral assuagement, as Foster contemplates, who sees Matthew using the story of the Canaanite woman to persuade some still reluctant conservative members to embrace the expansion (Foster 2004:227), but Matthew may simply be being informative. I think Foster is right about Matthew's commitment to Gentile mission, not least because of our findings above, including 25:31-46, but also in his arguing in the light of 24:9, 14 that we misread Matthew if we see him as standing on the cusp of the Gentile mission and trying to persuade his hearers to 'get on board', so to speak (Foster 2004:235; Luz 1995:16). The gospel reads more like the Gentile mission has been underway for some time, time enough for considerable subtle reflection. Sermons in Matthew's community and reflected in his gospel have long since been addressing them along with all the other members of the church as the final judgement scene shows. The parable of the royal wedding feast (22:1-14) appears to reflect a moving on from mission to the Jews and its rejection punished by the destruction of Jerusalem in $70 \mathrm{CE}$ to mission also (but not only!) to the Gentiles to now a situation where those who have responded positively need to be reminded that belonging is ultimately just as much about wearing the garments of righteousness as it was when John and Jesus confronted their contemporaries.

I, therefore, find unconvincing the accounts which see Matthew and his community poised to embrace Gentile mission or having only very recently done so and Matthew writing his gospel in part to persuade and encourage the move (cf. Kraus 2011:212). If it was critical, von hoher aktueller Bedeutung, as Konradt (2016:22) puts it, then one would expect to see something more than what we have, which apart from 28:18-20 consists primarily of indirect allusions. These allusions to Gentiles do not, however, read as newly devised arguments to warrant a recent decision to open the community to Gentile mission. They appear too well ingrained in the narrative. The move has been made some time ago, even though the community remembers that it was not as immediate as the instruction in 28:18-20 would suggest it should have been.

The actual exposition of the Law by Jesus according to Matthew also indicates at a number of points that Gentiles are assumed to belong, despite Matthew's retaining traditions which use 'Gentile' to indicate what is inferior (5:46-47; 6:7-8; 18:15-17). Presumably Gentiles who had converted would have agreed. It was after all why they converted (Konradt 2016:19; cf. Sim 1995:25-30, 41-43, who has Matthew end his gospel with a command which was, he alleges, inapplicable to his hearers). This all suggests that beside the strongly Jewish context there is also a presence of Gentiles within the Matthean community and has been around long enough for problems to arise and for a Christology to have developed which presents Jesus in universal focus.

Matthew's concern with ethical behaviour and its neglect among some who otherwise claim the Spirit's power and presence in miracle and worship is a regular theme, from the climax of the Sermon on the Mount to the final parables of Jesus' ministry. In John's preaching the challenge to bear fruit is addressed to Pharisees and Sadducees. In Matthew's account of Jesus' preaching it has a dual focus matching the two stages of Jesus' ministry and the time of the church. There is a consistently sharp edge to the ethical challenges of Matthew's Jesus. At times it recalls Paul's challenges to the Corinthians, but its consistency suggests that the target is not something going on far away, such as in Pauline or postPauline churches, but something close to home. Nothing in such exhortations suggests that the problems are specific to Gentile believers, outside or inside the community.

Can one say more? Others have noted the potential for what I call hermeneutical contamination, which in the past has skewed historical reconstruction through stereotypes of Judaism and Jewishness which have been exposed as doing injustice to the texts, not to speak, of indirectly supporting anti-Jewishness. There is an ecumenical casuistry, on the other side, which seeks to harmonise as much as possible early Christian movements with their fellow Jewish movements. The debate about Matthew is not exempt from these dangers. What has emerged over the past two decades is that one can speak of Matthew's spirituality or soteriology as having a Jewish structure, with its Christology serving to holding the centrality of Torah in its proper place from a Jewish perspective. Vigorous debate over its interpretation, as reflected in Matthew, belongs well within Judaism.

The two major factors which threaten the stability of this reconstruction of Matthaean Judaism are Gentile mission and Matthaean Christology. The evidence suggests that this is a community which has engaged in mission, including to Gentiles, and, even if treating them as proselytes and circumcising them, which is far from certain, their presence will have posed problems, at least in the eyes of other Jews (Konradt 2016:37; Loader 2015b:131). They do not appear to 
be numerous, which somewhat alleviates the problem (Konradt 2016:37) and we may assume their observance of Torah, and their willingness to sit submissively though not uncritically under local Jewish administration, as 23:3 enjoined. Probably the association of the community with the rest of the Christian movement, which had much greater Gentile strength, was a greater problem, than having some Gentiles, themselves.

Matthew may have been familiar with predominantly Gentile forms of Christianity. It makes sense to hear Matthew's Jesus disowning of those who drop parts of Torah as addressing problems he sees outside his own community. There were various options, which include Pauline communities. Certainly he knew Mark and for all his valuing of Mark's Christology and sustaining its emphasis on Jesus as God's Son and Messiah and as one whose death was in some sense vicarious, he was clearly unhappy with Mark's dismissal of food laws. Apart from that, as we have noted, he would have strongly affirmed Mark's understanding of what enables one to inherit eternal life, namely keeping the commandments, above all, the ethical ones, and following Jesus (Mk 10:16-22), and would not have found Paul's answer of faith in Christ alone apart from the Law as acceptable, though nowhere does he indicates he is aware of it. For the only place where reference is directly made to people teaching what is unacceptable is about setting some laws aside (5:19). That fits Mark better than Paul. One might however see in the global statement about abolition in 5:17 an allusion to some who go further, like Paul and his successors, though I am rather convinced that if so it is directed not against antinomians, but against those having to deal with accusations that to follow Jesus implied as much (cf. Sim 2011:180-88; and on alleged anti-Paulinism in Matthew; Sim 2007).

Matthew's reworking of Mark's liberation model to redefine Jesus' role to be not only Messiah but universal judge effectively transforms soteriology into a form of Judaism according to which acceptance of a place in God's people is to be matched by doing God's will as set out in Torah and expounded by Jesus. Aside from its claims about Jesus' status in which Matthew goes even beyond Mark and which Jewish eyes would have seen as extravagant and blasphemous, Matthew's gospel (re-)incorporates Mark's Jesus into Judaism and the pattern of covenantal nomism. It does so however in a manner that prioritises those values in Torah that are universal, rather than the cultic and ceremonial, making its form of Judaism attractive to its Gentile members and potential members and perhaps doing so in response to them or at least to engagement with the wider Gentile world which had led other Jewish writers also to stress universal values.

The second major issue is Christology, which certainly comes to the fore in Matthew 1-4. While Matthew asserts the significance of Jesus in thoroughly Jewish terms as Messiah, and on the basis of strongly Jewish presuppositions about fulfilment, typological correspondence, divine interventions and patterns, reflecting that the claim to fulfil Jewish hope matters and Jewish arguments count, there are claims that go far beyond this.
At one level Matthew is probably having to defend the alleged miraculous conception against slander imputing shameful misconduct on the part of Mary, which must have been (like the allegations about the resurrection), sufficiently close to home to need addressing. At another level, while on the Law and even soteriology Matthew and the synagogue might agree (and have room for disagreement on various aspects); on Christology, increasingly, they could not. The grounds for the latter are already evident in the extraordinary claims implied in the opening chapters about Jesus as miraculously conceived Son of God and as Emmanuel, possibly tolerable, which foreshadow identification of Jesus with Sophia and Shekinah, probably intolerable. The claims that Jesus is Son of Man and universal judge are not far behind, as is the assumption that beside Torah is another authority equal to it in the person of Jesus, even though upholding it.

If in the middle decades of the first century tensions with fellow Jews were over Torah, in the latter decades they became increasingly focused on the acceptability of claims made about Jesus, even in relation to groups like Matthew's which on matters of Torah sat well within Judaism of the time. Matthew and his community might continue to claim belonging. I suspect that most Jews would have rejected the claim and affirmed the judgement of Caiaphas about not only Jesus but also his followers. Matthew must have known that.

Nothing in these chapters of the gospel suggests a conscious break with the dominant Judaism of its context, as we find in John, though much suggests conflict and clearly Matthew's group meets apart from the synagogue (Konradt 2016:5-6). As Hagner notes, that, in itself, need not imply separation from Judaism, though it places them in a kind of no man's land 'between their Jewish brothers and sisters, on the one hand, and gentile Christians, on the other' (Hagner 1993:1xx). Over time such conflict would become intolerable. Matthew appears not to have disowned the wider Jewish community, but in vain to have claimed to own it or own leadership of it, to be the new legitimate tenants in its vineyard (21:43) (Foster 2004:232; Konradt 2007:198; Kraus 2011:225), and to have blamed the citizens of Jerusalem for the debacle of $70 \mathrm{CE}$ (27:25). For its part, that community would find the escalating claims made about Jesus increasingly intolerable to the point where they could no longer own Matthew's movement as being in the same category as others within the fold. I suspect that if one could ask people from both sides about belonging, one might find diverse answers on both sides.

If we assume a strongly Jewish context, apparently under local Jewish administration, in which a predominantly Jewish Christian community also includes Gentiles, sometime in the 80s CE, then one possible location could be in a part of Agrippa 2's territory, which we know to have stretched eventually far to the north. For the territory of Agrippa 2, who died ca $100 \mathrm{CE}$, extended well into Syria after the Jewish war according to Photius (Bibl. 33; cf. also Dio 66.15.4), as far as Arca north east of Tripolis in northern Lebanon according to Josephus, (B.J. 3.57-58; 7.97) (see Kokkinos 1998:331-41). 
Kraus observes: Die Zehntabgabe gilt m.W. nur für das Hl. Land (Kraus 2011:236). Die Vorstellung vom Hl. Land in 4,25 könnte für eine Situierung im Hl. Land sprechen (Kraus 2011:238). That might make best sense of 23:2 which appears to presuppose local administration being in the hand of synagogue authorities, less likely around Antioch, where some locate Matthew. The same broader setting has been suggested for John's gospel, though the two traditions have little in common and so would have had to have had little contact, and John's communities live on the broken side of a tense and bitter relationship which their christological claims made untenable.

\section{Acknowledgements Competing interests}

The author declares to he has no financial or personal relationships which may have inappropriately influenced him in writing this article.

\section{References}

Brown, R.E., 1993, The Birth of the Messiah: A commentary on the infancy narratives in the Gospels of Matthew and Luke, 2nd edn., Doubleday, New York.

Carter, W., 2000, Matthew and the margins: A sociopolitical and religious reading, Orbis, New York.

Carter, W., 2005, 'Matthaean Christology in Roman imperial key: Matthew 1.1', in J. Riches \& D.C. Sim (eds.), The Gospel of Matthew in its Roman imperial context, pp. 143-165, T\&T Clark, London.

Charette, B., 1992, The theme of recompense in Matthew's Gospel, JSNTS 79, JSOT Press, Sheffield.

Davies, W.D. \& Allison, D.C., 1988/1991/1997, A critical and exegetical commentary on the Gospel according to Saint Matthew, 3 vols, ICC, T\&T Clark, Edinburgh.

Foster, P., 2004, Community, law and mission in Matthew's Gospel, WUNT 2.177 Mohr Siebeck, Tübingen.

France, R.T., 2007, The Gospel of Matthew, NICNT, Eerdmans, Grand Rapids, MI.

Hagner, D.A., 1993/1995, Matthew, vols, WBC 33AB, Word, Dallas, TX.

Kennedy, J., 2008, The recapitulation of Israel: Use of Israel's history in Matthew 1:1-4:11, WUNT 2.257, Mohr Siebeck, Tübingen.
Kokkinos, N., 1998, The Herodian dynasty: Origins, role in society and eclipse, JSPSS 30, Sheffield Academic Press, Sheffield.

Konradt, M., 2007, Israel, Kirche und die Völker im Matthäusevangelium, WUNT 215, Mohr Siebeck, Tübingen.

Konradt, M., 2016, 'Matthäus im Kontext. Eine Bestandsaufnahme zur Frage des Verhältnisses der matthäischen Gemeinde(n) zum Judentum', in Studien zum Matthäusstudien, WUNT 358, pp. 3-43, Mohr Siebeck, Tübingen.

Kraus, W., 2011, 'Zur Ekklesiologie des Matthäusevangeliums', in D. Senior (ed.), The Gospel of Matthew at the crossroads of early Christianity, BETL 243, pp. 195-240, Peeters, Leuven.

Loader, W., 2012, The New Testament on sexuality, Eerdmans, Grand Rapids, MI.

Loader, W., 2014, 'The Concept of Faith in Paul and Mark', in I. Elmer, D.C. Sim \& O. Wischmeyer (eds.), Paul and Mark: Comparative essays Part I: Two authors at the beginnings of Christianity, BZNW 198, pp. 423-464, de Gruyter, Berlin.

Loader, W., 2015a, 'Did adultery mandate divorce? A Reassessment of Jesus' Divorce Logia', NTS 61, 67-78. doi: http://dx.doi.org/10.1017/\$0028688514000241

Loader, W., 2015b, 'Neuere Tendenzen in der Matthausforschung', in W. Kraus \& M. Rösel (eds.), Update-Exegese 2.1. Ergebnisse gegenwärtiger Bibelwissenschaft, pp. 122-133, Evangelische Verlagsanstalt, Leipzig.

Luz, U., 1995, The theology of the Gospel of Matthew, Cambridge University Press, Cambridge.

Luz, U., 2002, Das Evangelium nach Matthäus (Mt 1-7), 2nd edn., EKK 1/1, NeukirchenVluyn, Neukirchener Verlag, Zurich, Benziger.

Majordomo-Marin, M., 1998, Den Anfang horen. Leserorientierte Evangelienexegese am Beispiel von Matthaus 1-2, FRLANT 180, Vandenhoeck \& Ruprecht, Göttingen.

Nolland, J., 2005, The Gospel of Matthew: A commentary on the Greek text, NIGTC, Eerdmans, Grand Rapids, MI.

Repschinski, B., 2009, Nicht aufzulösen sondern zu erfüllen. Das jüdische Gesetz in den synoptischen Jesus Erzählungen, FzB 120, Echter, Würzburg.

Senior, D., 2011, 'Matthew at the crossroads of early Christianity: An introductory assessment', in D. Senior (ed.), The Gospel of Matthew at the crossroads of early Christianity, BETL 243, pp. 3-23, Peeters, Leuven.

Sim, D.C., 1993, 'The "confession" of the soldiers in Matthew 27.54', HeyJ 34, 401-424.

Sim, D.C., 1995, 'The Gospel of Matthew and the Gentiles', JSNT 57, 19-48. doi: http:// dx.doi.org/10.1177/0142064x9501705702

Sim, D.C., 2005, 'Rome in Matthew's Eschatology', in J. Riches \& D.C. Sim (eds.), The Gospel of Matthew in its Roman imperial context, pp. 91-106, T\&T Clark, London.

Sim, D.C., 2007, 'Matthew 7.21-23: Further Evidence of Its Anti-Pauline Perspective', NTS 53, 325-343. doi: http://dx.doi.org/10.1017/S0028688507000161

Sim, D.C., 2011, 'Matthew's use of Mark: Did Matthew intend to supplement or to replace his primary source?' NTS 57, 176-192. doi: http://dx.doi.org/10.1017/ S0028688510000366

Varkey, M., 2014, 'Salvation in continuity: A reconsideration of Matthew's soteriology', PhD Dissertation, Murdoch University.

Weaver, D., 2005, "'Thus you will know them by their fruits": The Roman characters of the Gospel of Matthew', in J. Riches \& D.C. Sim (eds.), The Gospel of Matthew in its Roman imperial context, pp. 107-127, T\&T Clark, London. 